\title{
Drug dependence among patients attending a Department of Venereology
}

\author{
MISS L. I. PONTING AND DR. C. S. NICOL \\ Lydia Clinic, St. Thomas' Hospital, London
}

THIS study is mainly the work of a Welfare Officer in a Venereal Disease Clinic and has been undertaken in combination with contact-tracing. An improved method of contact-tracing was described by Muspratt and Ponting (1967).

\section{Method}

At their first attendance all patients were asked by the doctor whether they had taken drugs during the last 3 years. In 1968, out of 7,973 patients, 249 ( 3.1 per cent.) admitted to being drug users. It was not possible to interview all of these, but data were obtained from 146 males and sixty females. Patient co-operation was excellent and not one refused to be interviewed.

\section{Results}

Of the sixty females, 22 were solely cannabis users and eighteen used only amphetamines. The remaining twenty had experimented with a number of drugs. Two who were addicted admitted to being 'pushers' so as to obtain extra drugs; of the other two, one was addicted to heroin and the other to amphetamines.

Of the 146 males, 66 were solely cannabis users, 23 used only amphetamines, one had experimented with opium abroad, one was addicted to heroin, and one to amphetamines. Three males who were addicts admitted to being 'pushers' so as to obtain extra drugs. Forty-five had experimented with a number of drugs.

The findings are set out in the Table (overleaf).

The majority had been introduced to drugs by friends, and stated that once one was on drugs one soon learnt to recognize the people who peddled them.

Among the reasons given for drug taking were the following:

(1) The need to keep awake for work or parties.

(2) Just for kicks.

(3) Because it was the done thing.

(4) Curiosity.

(5) Boredom.

(6) Inability to make friends.

(7) Introversion.

(8) Depression.

(9) Inferiority complex.

(10) Escape from reality.

(11) Loneliness.

(12) Searching for something and never finding it.

(13) Relaxation.

(14) To increase perception.

(15) A number of the coloured patients stated that they had previously lived in areas where hemp was grown, it was the normal thing for males to smoke, and they did not regard it as a drug.

Fifteen males and nine females had had psychiatric treatment, not necessarily for drug taking.

Nineteen males and eight females (including four prostitutes) had been in trouble with the police, again not necessarily for drug taking.

\section{Patients' comments}

Many felt that the use of cannabis should be made legal; they stated that after smoking cannabis there was no hangover and that it was more social than antisocial. •Several who had experimented with L.S.D. stated that it was not a drug to take lightly and that you should always have somebody with you. Some expressed a desire to try L.S.D. The suggestion was put forward that young people who had been involved in drug taking and had sometimes seen tragic results in others, should play a more active role in school and youth club programmes on drug taking. There was a general feeling that too much publicity was given to the drug habits of well-known people, especially members of pop groups. Some felt that it was unfair that young people should be in trouble for drug taking, when so many adults took tranquillizers and sleeping tablets.

Prices varied: cannabis as a rule was $5 s$. a cigarette, amphetamines $1 s .6 d$. to $2 s$. per tablet, and methedrine 5s. a shot. 
T A B L E Findings in a study of drug dependence in 146 men and 60 women attending $a V$.D. clinic

\begin{tabular}{|c|c|c|c|}
\hline \multicolumn{2}{|l|}{ Sex } & \multirow{2}{*}{$\frac{\text { Male }}{146}$} & \multirow{2}{*}{$\frac{\text { Female }}{60}$} \\
\hline No. of cases & & & \\
\hline Average age (yrs) & $\begin{array}{l}15-20 \\
21-25 \\
26-30 \\
\text { over } 30\end{array}$ & $\begin{array}{l}47 \\
62 \\
23 \\
14\end{array}$ & $\begin{array}{r}29 \\
19 \\
8 \\
4\end{array}$ \\
\hline Nationality & $\begin{array}{l}\text { British } \\
\text { Other } \\
\text { Coloured }\end{array}$ & $\begin{array}{l}98 \\
21 \\
27\end{array}$ & $\begin{array}{r}47 \\
10 \\
3\end{array}$ \\
\hline Employment & $\begin{array}{l}\text { Regular } \\
\text { Occasional } \\
\text { Unemployed }\end{array}$ & $\begin{array}{r}129 \\
8 \\
9\end{array}$ & $\frac{48}{12}$ \\
\hline Type of employment & $\begin{array}{l}\text { Professional } \\
\text { Musicians and actors } \\
\text { Skilled } \\
\text { Semiskilled } \\
\text { Unskilled } \\
\text { Students } \\
\text { Prostitutes } \\
\text { Unemployed }\end{array}$ & $\begin{array}{l}14 \\
18 \\
15 \\
49 \\
27 \\
\frac{14}{9}\end{array}$ & $\begin{array}{c}4 \\
11 \\
18 \\
7 \\
4 \\
4 \\
12^{\star}\end{array}$ \\
\hline Sexual orientation & $\begin{array}{l}\text { Heterosexual Steady } \\
\begin{array}{l}\text { Casual } \\
\text { Paid }\end{array} \\
\text { Homosexual Steady } \\
\text { Bisexual Casual } \\
\text { Married } \\
\text { Extramarital sexual } \\
\text { intercourse }\end{array}$ & $\begin{array}{r}18 \\
82 \\
8 \\
1 \\
11 \\
5 \\
21 \\
15\end{array}$ & $\begin{array}{r}21 \\
28 \\
4 \\
-\end{array}$ \\
\hline Drugs taken & $\begin{array}{l}\text { Amphetamines } \\
\text { L.S.D. } \\
\text { Hashish } \\
\text { Heroin }\end{array}$ & $\begin{array}{r}69 \\
11 \\
100 \\
6\end{array}$ & $\begin{array}{r}37 \\
3 \\
35 \\
5\end{array}$ \\
\hline Frequency & $\begin{array}{l}\text { Once } \\
\text { Occasional } \\
\text { Regular } \\
\text { Dependent }\end{array}$ & $\begin{array}{r}18 \\
90 \\
33 \\
5\end{array}$ & $\begin{array}{r}5 \\
40 \\
11 \\
4\end{array}$ \\
\hline
\end{tabular}

^This includes housewives

\section{Case histories}

Case 1, an English youth aged 19 years, was the only child of working-class parents, with no special family problems. He had had comprehensive school education until the age of 15 years. He did not like school, the only subjects that interested him being drawing and painting. At 14 years he became a member of a gang. He thought it clever to take drugs, started on 'French Blues', and experimented with most other drugs. At first he felt no end of a fellow, but the effects soon wore off. He had been in trouble with the police, had had psychiatric treatment, and had been in and out of jobs. He lived with a girl for a short while, during which time he worked and gave up drugs. He later experimented with methedrine; this decreased his libido.

Case 2, an English man aged 23 years, had a good family background, was the youngest of the family, and had been 'spoilt'. He had had a grammar school and university education. He was very lonely and found it difficult to make friends. When he succeeded in forming a friendship, he discovered that the friend was taking drugs. He started taking amphetamines, and found it easier to relax and form part of a group. He had experimented with hashish and L.S.D., but recently made himself give up drugs as he did not wish to become dependent, but once again finds it difficult to mix.

Case 3, an English youth aged 17 years, had left home because his father was too strict. He had had a comprehensive school education, but was not working, stating that he had contracted out. He shares a flat with a British West Indian who is working. He smokes cannabis and takes methedrine, and states that 'When people cease to provide me with drugs, I shall cease to take them'. He and his friend give parties, and the guests, who are aged between 17 and 29 years, are only admitted if they give them either drugs or money. He stated that he had never taken an overdose. Asked if sexual intercourse took place at these parties he said 'No, they only listen to music'.

Case 4, an English girl aged 19 years, was the youngest in the family, and educated in a convent school. At 18 years she came to live with friends in London; she was not working, and lived rather a gay life. At one party they were taking 'French Blues', and as she did not wish to be out of things she took some too. She then found it easier to mix and keep late hours, but it was necessary to take more and more. The family thought that she should work, so she only took drugs at weekends. She was unable to concentrate and became more and more depressed, so she decided that the only solution was to return home and inform her parents. She was admitted to hospital but took her own discharge two weeks later and returned to London. Before long she was back on drugs, this time hashish and methedrine; she became depressed, lost her appetite, and was unable to sleep. After two months she was horrified at her appearance and made a determined effort to give up drugs for good. She states that she now realizes that it is possible to have a good time without taking drugs.

\section{Summary}

This study has shown that $3 \cdot 1$ per cent. of patients of all ages attending a venereal disease clinic in London had had experience of drug taking in the three years examined. This may be compared with 18.2 per cent. in Linken's selected group of young adults.

The users were divided into three groups:

(1) Those who had taken drugs once only.

(2) Occasional users.

(3) Regular users, but not necessarily dependent.

The majority were occasional users who took the drugs at weekends or in the evenings. Contrary to the findings of Linken (1968), their heterosexual relationships were mainly casual. The drugs of choice were hashish and amphetamines; of the latter, 24 males and eleven girls had taken methedrine. Apart from the study of Linken, who completed a question- 
naire on drug taking for 252 patients below 30 years of age attending a venereal disease clinic in London, little has been published on this subject.

\section{References}

Linken, A. (1968). Brit. F. vener. Dis., 44, 337.

Muspratt, B., and Ponting, L. I. (1967). Ibid., 43, 204.

\section{Dépendance aux drogues addictives chez les consultants d'un service de vénéréologie}

\section{SOMMAIRE}

La présente étude a montré que 3,1 pour cent des malades de tout âge fréquentant une clinique vénéréologique à Londres avaient pris des drogues addictives au cours des trois ans précédant l'enquête. Ceci peut se comparer avec le chiffre de 18,2 pour cent trouvé par Linken, dans un groupe choisi de jeunes adultes.

Les sujets peuvent être divisés en trois groupes:

(1) Ceux qui ont pris des drogues une fois seulement;

(2) Les utilisateurs occasionnels;

(3) Les utilisateurs réguliers, sans être nécessairement dépendants de la drogue.

La majorité était des utilisateurs occasionnels, qui prenaient des drogues en fin de semaine ou au cours de soirées. Contrairement aux constatations de Linken (1968), pour les rapports hétérosexuels, les partenaires étaient généralement occasionnelles. Les drogues recherchées étaient le haschich et les amphétamines; pour ce dernier groupe, 24 garçons et 11 filles avaient pris de la méthédrine. Sauf le travail de Linken, qui a rendu compte d'une étude par questionnaire sur la prise de drogue chez 252 malades de moins de 30 ans consultant en clinique vénéréologique de Londres, peu de chose a été publié sur ce sujet. 